\title{
VETERINARY TREATMENT OF AN INJURED WILD FRANCISCANA DOLPHIN CALF (Pontoporia blainvillei, Gervais \& D’Orbigny, 1844)
}

\author{
Paula Baldassin ${ }^{1,2}$; Max Rondon Werneck ${ }^{2,3}$; Carla Beatriz Barbosa ${ }^{1,2}$; \\ Berenice Maria Gomes Gallo ${ }^{2,3}$; Hugo Gallo ${ }^{1,2}$ and Michael Walsh ${ }^{4}$
}

The Franciscana dolphin (Pontoporia blainvillei) is a small ranging from Espírito Santo, Brazil $\left(18^{\circ} 25^{\prime} S\right)$ to Golfo Nuevo, Península Valdés, Argentina (42³5'S) (Kinas, 2002). It appears to inhabit a narrow strip of coastal waters between the surf line and the $30-\mathrm{m}$ isobath. Its conservation is of particular concern because of its restricted distribution and vulnerability to incidental capture in fishing gear (Reeves et al., 2003). Between 1997 and 2001, 109 stranded animals, among which 28 living calves that could not be rescued, were observed in the coastal region of São Paulo, Brazil (Santos et al., 2002).

Located in the north of São Paulo State, Brazil, the Ubatuba Aquarium and Argonaut Institute for Costal and Marine Conservation have worked in the rehabilitation of marine animals since 1996. Four other franciscana dolphin calves, including two males and two females, were treated in Ubatuba. One of these calves had been caught in nets.

This case report describes the husbandry and medical management of an injured orphan female Pontoporia blainvillei calf entangled in a fishing net, and rescued by a diver in the shallow waters of São Sebastião, São Paulo state $\left(23^{\circ} 21^{\prime} 20^{\prime \prime} S\right)$ on 9 January 2006. Physical examination and blood glucose test were performed on site by the rescue team. Blood glucose level was $86 \mathrm{mg} / \mathrm{dl}$ and the respiratory rate was 5 breathes per minute. The animal was transported to the Ubatuba Aquarium (23⒉ $26^{\prime} 13^{\prime \prime} S$ ) by car on foam transported dry and wet down with sea water for evaluation and rehabilitation. It was maintained in a $1,000-\mathrm{L}$ pool filled with sea water at $25^{\circ} \mathrm{C}$ and $35 \mathrm{ppm}$ salinity, which was all changed after each feeding. The calf measured $76 \mathrm{~cm}$, weighed $5 \mathrm{~kg}$ and had a body temperature of $36.4^{\circ} \mathrm{C}$. It presented with several abrasions on the rostrum. The umbilical cord was already detached with no signs of fetal folds. Teeth were partially erupted and no hair was observed on the rostrum. These observations suggest that the calf was about three months old. The teeth development indicated that it was already able to consume small amounts of fish. Feces were green in color, with a pasty consistency.

Heart rate and respiratory frequency were measured every 30 minutes. The heart rate ranged from 99 to 139 per minute and the respiratory rate from 5 to 9 per minute. Respiration frequency increased initially after cetacean endemic to the western South Atlantic Ocean,

handling but returned to normal shortly after release. The animal was alert but exhibited some abnormal swimming posture and appeared to be uncomfortable as evidenced by abdominal flexing and shivering. The water temperature was subsequently increased to $28^{\circ} \mathrm{C}$ and the animal began swimming normally.

Prophylactic anti-microbial therapy was initiated with a daily intramuscular injection of $5 \mathrm{mg} / \mathrm{kg}$ amikacin sulfate twice a day (Stoskopf, 1990). A milk replacer used at Sea World California and other marine parks was prepared and the animal was fed every $1.5 \mathrm{~h}$ (Table 1) by bottle. The feeding frequency followed the natural patterns known for dolphins, which include nursing intervals between $30 \mathrm{~min}$ and 2 hours with a 20-sec duration for each session (Jones et al., 19885; Sweeney, 1990). The rostrum lesions were treated with a combination of Cicatrilex ${ }^{\circledR}$, a waterproof ointment, and Quadriderm ${ }^{\circledR}$ (Gentamicin, Betamethasone, Tolnaftate and Iodoclorohidroxiquina). Three blood samples were collected from the central tail vein, with a 19 gauge butterfly and a 3-cc syringe (Table 2).

Table 1. Milk formula administered to the franciscana dolphin from this study, adapted from formula used at Sea World California (Young and Dalton, 1994*) but modified based on the oil available.

\begin{tabular}{c}
\hline \hline MiLK COMPOSITION (1 LITER) \\
\hline \hline $280 \mathrm{~g}$ fish fillet (Sardina pilchardus) \\
$50 \mathrm{~g}$ zoologic 30/55 \\
$90 \mathrm{~g}$ zoologic 33/40 \\
$1 / 2$ tablet soy lecithin \\
$7.25 \mathrm{~g}$ glucose \\
$62 \mathrm{mg}$ taurine \\
$4.5 \mathrm{~g}$ NaCl \\
1.2g (18.75g) dicalcium phosphate \\
25ml cod liver oil \\
550ml filtered tap water/milk without lactose \\
50ml milk cream without lactose \\
\hline \hline \\
*Young, W. G. and Dalton, L. M. (1994) Treatment of a live \\
stranded young Risso's dolphin (Grampus griseus) Page 140 \\
in Abstracts, International Association of Aquatic Animal \\
Medicine Annual Conference. 11-14 May. Vallejo, CA, USA.
\end{tabular}

\footnotetext{
${ }^{1}$ Aquario de Ubatuba. Rua Guarani, 859. Ubatuba, São Paulo, Brazil. E-mail: veterinaria@aquariodeubatuba.com.br.

${ }^{2}$ Instituto Argonauta para a Conservação Costeira e Marinha. Rua Guarani, 835. Ubatuba, São Paulo, Brazil.

${ }^{3}$ Fundação Pró-Tamar, Base Ubatuba. Rua Antonio Athanásio da Silva, 273. Ubatuba, São Paulo, Brazil.

${ }^{4}$ Aquatic Animal Health Program, University of Florida, 2015 SW $16^{\text {th }}$ Ave, Gainesville FL, 32610, USA.

${ }^{5}$ Jones, M.H., Otten, T., Smith, R. and Houck, J. (1988) Neonatal care of a stranded harbor porpoise, Phocoena phocoena. Pages 165-169 in Abstracts, International Association of Aquatic Animal Medicine Annual Conference. 23-26 May. Orlando, FL, USA.
} 
Table 2. CBC results for the Franciscana dolphin during rehabilitation.

\begin{tabular}{|c|c|c|c|}
\hline & \multicolumn{3}{|c|}{ HEMOGRAM } \\
\hline & 09 JAN 2006 & 11 JAN 2006 & 13 JAN 2006 \\
\hline Erythrocytes (millions $/ \mathrm{mm}^{3}$ ) & 4.23 & 4.56 & 4.77 \\
\hline Hematocrit (\%) & 47 & 51 & 55 \\
\hline Hemoglobin $(\mathrm{g} / \%)$ & 15.5 & 16.3 & 17.7 \\
\hline $\operatorname{MCV}\left(\mu^{3}\right)$ & 111.11 & 111.84 & 115.30 \\
\hline $\mathrm{MCH}(\mathrm{pg})$ & 36.64 & 35.74 & 37.10 \\
\hline $\mathrm{MCHC}(\%)$ & 32.97 & 31.96 & 32.18 \\
\hline Leukocytes $\left(\mathrm{mm}^{3}\right)$ & 4200 & 3500 & 900 \\
\hline Basophils (\%) & 0 & 0 & 0 \\
\hline Eosinophils (\%) & 2 & 3 & 0 \\
\hline Mielocytes (\%) & 0 & 0 & 0 \\
\hline Metamielocytes (\%) & 0 & 0 & 0 \\
\hline Band shaped (\%) & 1 & 2 & 1 \\
\hline Segmented (\%) & 60 & 60 & 68 \\
\hline Lymphocytes (\%) & 35 & 30 & 28 \\
\hline Monocytes (\%) & 2 & 5 & 3 \\
\hline Platelets (mil/mm³) & 189 & 155 & 120 \\
\hline
\end{tabular}

Whole blood glucose was measured three times a day (morning, pre-feeding, afternoon and night), with Accu-Chek Advantage ${ }^{\circledR}$. These ranged from 42 to $82 \mathrm{mg} / \mathrm{dl}$ and weren't consistently maintained. Blood glucose values showed large variation during the treatment and in periods of low glycemia the animal showed apathymild depression and slight trembling which may also be related to the lower water temperature. Glucose levels in milk were subsequently increased and the blood glucose levels stabilized. The increasing hematocrit and hemoglobin levels indicated that the dolphins deteriorating hydration status. The level of eosinophils was initially low. A decrease in the frequency of eosinophils has been observed in stressed cetaceans or when antiinflammatory medications were given (Bossart and Dierauf, 1990). The dolphin developed a leucopenia indicative of a severe bacterial or viral infection and died six days after rescue. Gross necropsy revealed a friable liver of light pink color and hyperemic lungs that had diffusely scattered areas of emphysema in the dorsal region. Histologically, the liver had mild to severe diffuse micro- and macro-vacuolization of the hepatocytes, indicative of diffuse vacuolar hepatopathy which can be related with nutritional disturb. The lungs showed mild congestion, edema and hemorrhagic points, and thickened alveolar septa. There were numerous macrophages in the alveolar lumen and heterophils in the capillaries, indicating acute interstitial pneumonia. Histological results suggest an infection process due to the association of the degenerative hepatic process with the lung and intestinal compromised.

Management of neonatal cetaceans can be complicated with clinical parameters changing very rapidly. Immune compromise and exposure to new bacterial flora in the environment requires an increase in surveillance for current and developing pathogens during the rehabilitation process. Additional diagnostic tests may include aerobic and anaerobic bacterial cultures, as well as yeast and fungal cultures from the respiratory system, gastric and rectum. Cytology from these systems is also recommended. Whenever possible, cultures and antibiotic sensitivity patterns should be used to guide antibiotic choice and the route of administration. Cytology may also help to determine the site of involvement and help in the choice of oral and parenteral antibiotics.

While initial CBC results indicated issues with dehydration as evidenced by an increasing hematocrit (Table 2) there is little published information on the normal ranges for these parameters of this species in the literature.

According to the IUCN (Cetacean Specialist Group, 1996), francicana dolphins are listed as "Data Deficient", meaning there is inadequate information to make a direct, or indirect, assessment of its risk of extinction based on its distribution and/or population status. The current lack of information on Pontoporia blainvillei emphasizes the need to improve veterinary health care, gather additional baseline information, and to implement and develop healthcare protocols for this species. 


\section{Acknowledgements}

The authors express their gratitude to Leonardo Teixeira from IBAMA - Caraguatatuba, Shirley Pacheco de Souza from Instituto Terra \& Mar, Fernando Alvarenga and trainees from Ubatuba Aquarium and Projeto Tamar IBAMA Base Ubatuba. We also thank Dr. Charles Manire and Dr. Marie-Françoise van Bressem for their helpful comments to the manuscript.

\section{References}

Bossart, G.D. ANd Dierauf, L.A. (1990) Marine mammal Clinical Laboratory medicine. Pages 1-52 in DIERAUF, L. A. (Ed.) Handbook of Marine Mammal Medicine, Health, Disease and Rehabilitation. Volume 2. CRC Press. Boca Raton, FL, USA.

Cetacean Specialist Group. (1996) Pontoporia blainvillei. In: IUCN 2006 Red List of Threatened Species. <www.iucnredlist.org>. Downloaded on 05 June 2007.

KINAS, P.G. (2002) The impact of incidental kills by gill nets on the Franciscana dolphin (Pontoporia blainvillei) in southern Brazil. Bulletin of Marine Science 70(2): 409-421.

ReEves, R.R., SMith, B.D., CResPo, E.A. AND Di SciarA, N.G. (2003) Dolphins, Whales and Porpoises: 2002-2010 Conservation Action Plan for the World's Cetaceans. IUCN/ SSC Cetacean Specialist Group. IUCN, Gland, Switzerland and Cambridge, United Kingdom.

Santos, M.C.O., Vicente, A.F.C., Zampirolli, E., Alvarenga, F.S. And SouzA, S.P. (2002) Records of Franciscana (Pontoporia blainvillei) from the coastal waters of São Paulo State, southeastern Brazil. The Latin American Journal of Aquatic Mammals 1(1): 169-174.

Stosкорғ, M.K. (1990) Marine Mammal Pharmacology. Pages 139-162 in Dierauf, L.A. (Ed.) Handbook of Marine Mammal Medicine, Health, Disease and Rehabilitation. Volume 2. CRC Press, Boca Raton, FL, USA.

SweEney, J.C. (1990) Marine mammal behavioral diagnostics. Pages 53-72 in Dierauf, L.A. (Ed.) Handbook of Marine Mammal Medicine, Health, Disease and Rehabilitation. Volume 2. CRC Press, Boca Raton, FL, USA. 
